\title{
Peningkatan Keaktifan dan Hasil Belajar Siswa Melalui Model Picture and Picture Berbantuan Media E-Komik
}

\section{Improving Student Activity and Learning Outcomes with Picture and Picture Model Assisted by E-Comic Media}

\section{Fuldiaratman $^{1^{*}}$, Minarni $^{1}$}

${ }^{1}$ Program Studi Pendidikan Kimia Jurusan PMIPA Fakultas Keguruan dan Ilmu Pendidikan Universitas Jambi, Indonesia

\begin{abstract}
A B S T R A K
Penelitian ini bertujuan untuk meningkatkan keaktifan dan hasil belajar siswa melalui pembelajaran yang dilaksanakan dengan model kooperatif picture and picture berbantuan e-komik. Aktivitas guru dan siswa diamati oleh observer dan direkam dalam bentuk video. Berdasarkan hasil observasi dan rekaman video dilakukan refleksi untuk perencanaan pembelajaran disiklus selanjutnya. Setiap akhir siklus diadakan postes. Data keaktifan dikumpulkan dengan metode observasi dan data hasil belajar dengan metode tes. Instrument berupa lembar observasi keaktifan guru, keaktifan siswa dan alat evaluasi berupa tes pilihan ganda untuk mengumpulkan data hasil belajar. Luaran yang dicapai atau diperoleh dari penelitian ini adalah Aktivitas guru dalam mengelola pembelajaran dengan menerapkan model picture and picture berbantuan media e-komik pada materi faktor-faktor yang mempengaruhi laju reaksi untuk setiap siklusnya berada pada kategori baik, yang mana pada siklus I dengan nilai rata-rata 78,57\% meningkat pada siklus II dengan nilai rata-rata $88,57 \%$. Aktivitas siswa pada saat penerapan model picture and picture berbantuan media ekomik pada materi faktor-faktor yang mempengaruhi laju reaksi adalah efektif, yang mana pada siklus I dengan nilai rata-rata $77,14 \%$ meningkat pada siklus II dengan nilai rata-rata 87,14\%. Hasil belajar siswa mengalami peningkatan dengan nilai rata-rata pada siklus I yaitu $66,66 \%$ dan siklus II yaitu 96,29\%. Dapat disimpulkan keaktifan belajar siswa dan hasil belajar siswa setelah penerapan model pembelajaran picture and picture berbantuan media e-komik terjadi peningkatan.
\end{abstract}

\section{$A B S T R A C T$}

This study's objective was to increase student activity and learn outcomes through learning carried out with the picture and picture cooperative model assisted by e-comics. The activities of the teacher and students were observed by the observer and recorded in the video. Based on observations and video recordings, reflection is made to plan the next cycle of learning. At the end of each cycle, a posttest was handled. The activity data were collected by the observation method and the learning outcome data by the test method. The instrument is an observation sheet of teacher activity, student activity, and an evaluation tool in the form of a multiple-choice test to collect data on learning outcomes. The output achieved or obtained from this study is the teacher's activity in managing learning by applying the picture and picture model assisted by e-comic media on the factors that affect the reaction rate for each cycle are in a suitable category, which in cycle I with an average value of $78.57 \%$ increase in cycle II with an average value of $88.57 \%$. Applying the picture and picture model assisted by e-comic media on the factors that affect the reaction rate lesson. In cycle I, with an average value of $77.14 \%$ increases in cycle II with an average value of $87,14 \%$. Student learning outcomes have increased with an average value in the first cycle of $66.66 \%$ and the second cycle of $96.29 \%$. This study's findings indicate that student learning activity and student learning outcomes after the application of the picture and picture learning model assisted by e-comic media have increased.

Kata kunci/Keyword $\quad$ : Model picture and picture; Aktivitas belajar; e-komik; picture and picture model; ecomic.

I N F O A R T I K E L

\begin{tabular}{l|l}
\hline Received: 21 Nov 2020; & $*$ coresponding author: fuldiaratman.fkip@unja.ac.id \\
Revised: 01 Dec 2020; & DOI: https://doi.org/10.22437/jisic.v12i2.11087 \\
Accepted: 04 Dec 2020 &
\end{tabular}




\section{PENDAHULUAN}

Tidak dapat dipungkiri bahwa yang turut menentukan sikap, mental, perilaku, kepribadian dan kecerdasan anak adalah pendidikan, pengalaman dan latihan-latihan yang diberikan dan dialami serta dilalui mereka sejak kecil. Pendidikan adalah mata rantai utama dalam proses peningkatan sumber daya manusia baik melalui lingkungan sekolah maupun diluar sekolah. Kesuksesan dalam mendidik anak sejak dini bergantung pada adanya keterkaitan antara lingkungan belajar dirumah dan disekolah (Rinaldi, 2006). Sehingga perlu adanya interaksi dan komunikasi antara anak, guru dan orangtua.

Suatu kegiatan pembelajaran hendaknya mengutamakan adanya interaksi dan komunikasi yang baik antara guru dan siswa terutama pada saat proses pembelajaran berlangsung. Sehingga kegiatan pembelajaran menjadi tempat bagi siswa untuk mengembangkan potensi yang ada dalam dirinya. Guru sebagai fasilitator pembelajaran, sudah sepatutnya memiliki kreatifitas yang tinggi melalui penggunaan model-model dan media pembelajaran yang sesuai agar siswa lebih termotivasi terhadap materi pembelajaran dan tidak mudah bosan (Mirza, Kamaruddin, \& Abdi, 2017).

Dari beberapa hasil penelitian tindakan kelas yang dilakukan oleh guru kimia, ditemukan permasalahan dalam proses pembelajaran materi laju reaksi yaitu berupa permasalahan rendahnya keaktifan siswa dalam proses pembelajaran. Hal ini didukung beberapa bukti hasil pengamatan terhadap siswa sebagai berikut: 1) Siswa kurang menunjukan interaksi yang positif dalam proses pembelajaran; 2) Siswa sangat jarang mengajukan pertanyaan; 3) Siswa kurang dalam mengemukakan pendapatnya di dalam pembelajaran; 4) Siswa sangat sedikit yang mengangkat tangan saat diberikan pertanyaan oleh guru.

Permasalahan tersebut muncul disebabkan oleh faktor-faktor sebagai berikut: 1) Pembelajaran masih berpusat pada guru; 2) Kurangnya penggunaan model pembelajaran, dalam hal ini guru mengajar hanya dengan menggunakan metode konvensional yaitu berupa ceramah; 3) Kurangnya penggunaan media pembelajaran yang menarik bagi siswa; 4) Kurangnya motivasi siswa dalam pembelajaran materi laju reaksi. Selain permasalahan rendanya keaktifan siswa, terdapat permasalahan lain berupa rendahnya hasil belajar siswa. Rendahnya hasil belajar siswa pada materi laju reaksi tercermin dari hasil belajar siswa pada aspek kognitif yang masih di bawah 70 (KKM).

Salah satu model pembelajaran yang sesuai diterapkan untuk mengatasi permasalahan tersebut adalah model kooperatif picture and picture. Model pembelajaran picture and picture merupakan model pembelajaran yang mengutamakan adanya kelompok-kelompok dengan menggunakan media gambar yang dipasangkan atau diurutkan menjadi urutan logis (Kurniasih \& Sani, 2015). Model pembelajaran picture and picture memiliki karakteristik yang kreatif, inovatif dan menyenangkan. Selain itu model ini dapat melatih siswa berpikir logis dan sistematis, sehingga sangat cocok digunakan dalam pembelajaran. Penerapan model pembelajaran picture and picture dalam mengatasi permasalahan tersebut didukung oleh beberapa alasan sebagai berikut: 1) Model picture and picture ini merupakan model kooperatif yang mengutamakan adanya kelompok-kelompok pembelajaran yang dilakukan secara berkelompok tersebut akan meningkatkan interaksi positif diantara siswa dengan siswa ataupun siswa dengan guru; 2) Pada model picture and picture siswa dilatih untuk mengemukan ide-ide atau pendapatnya sehingga siswa akan menjadi lebih aktif dalam mengemukakan pendapat; 3) Penggunaan media berupa gambar memudahkan guru dalam menjelaskan, selain itu juga memudahkan siswa dalam mengerti apa yang dijelaskan oleh guru; 4) Salah satu keunggulan model picture and picture ini adalah memunculkan motivasi belajar siswa ke arah yang lebih baik, dengan meningkatnya motivasi siswa dalam belajar, 
akan sejalan dengan peningkatan minat siswa terhadap pembelajaran tersebut dan pada akhirnya akan sejalan dengan peningkatan hasil belajar siswa.

Supaya penerapan model pembelajaran picture and picture ini dapat berjalan dengan efektif dan optimal, perlu menggunakan bantuan media pembelajaran yang inovatif. Media pembelajaran dapat diartikan sebagai segala sesuatu yang dapat digunakan untuk menyalurkan pesan (message), merangsang pikiran, perasaan, perhatian dan kemauan siswa sehingga dapat mendorong proses belajar (Puspitasari, Surjono, \& Minghat, 2018). Media pembelajaran memiliki fungsi dan peranan yang sangat vital dalam pembelajaran. Karena penggunaan media pembelajaran selain dapat membantu guru dalam menyampaikan materi-materi yang sulit dipahami siswa juga dapat menciptakan suasana belajar yang menyenangkan serta mampu untuk mengasah keterampilanketerampilan tertentu yang dikehendaki oleh guru (Elisa \& Wiratmaja, 2019).

Pemilihan media pembelajaran yang tepat dan sesuai dengan tujuan yang ingin dicapai akan menjadikan proses pembelajaran menjadi lebih efektif. Berbagai kajian telah melaporkan bahwa seseorang telah mampu meningkatkan pengetahuaanya melalui penggunaan teknologi pembelajaran terutama teknologi informasi, sehingga dapat hidup layak di masyarakat (Rusdi, 2009).

Dewasa ini perkembangan teknologi pembelajaran telah meningkat dengan pesat, yang menjadikan guru memiliki banyak pilihan untuk menggunakan media pembelajaran mana yang paling sesuai dengan karakteristik siswa dan materi pelajaran yang akan disampaikan. Salah satu media inovatif berbasis teknologi informasi dan komunikasi terkini yang dapat digunakan untuk mendukung pelaksanaan model picture and picture adalah media e-komik. E-komik merupakan rangkaian gambar-gambar serta lambang-lambang dalam urutan tertentu dengan tujuan untuk menyampaikan informasi kepada pembacanya. E-komik adalah media komunikasi visual yang mempunyai kekuatan untuk menyampaikan informasi secara populer dan mudah dimengerti. Dengan bantuan media e-komik ini diharapkan proses pembelajaran menjadi lebih efektif dan menyenangkan, sehingga mendorong motivasi siswa dalam belajar ke arah yang lebih baik.

\section{METODE PENELITIAN}

Penelitian ini termasuk kedalam Penelitian Tindakan Kelas (PTK) atau Classroom Action Research. Pada penelitian ini akan mendapatkan data yang bersifat kualitatif dari 3 sumber. Subjek penelitian adalah siswa kelas XI MIA 1 SMA N 7 Sarolangun. Jumlah siswa sebanyak 27 orang yang terdiri laki-laki dan perempuan. Pengambilan subjek penelitian ditentukan mengingat hasil belajar siswa kelas XI MIA yang masih dibawah KKM yang telah ditentukan. Sedangkan objek penelitian ini yaitu penggunaan model picture and picture berbantuan media e-komik pada mata pelajaran kimia materi laju. Adapun instrumen peneliti yang digunakan dalam penelitian ini adalah lembar observasi aktivitas siswa, pedoman wawancara untuk meminta tanggapan guru, soal tes, dan video pembelajaran.

Penelitian tindakan kelas yang dilakukan menggunakan model Kurt Lewin yang terdiri dari empat komponen, yaitu perencanaan (planning), tindakan (acting), pengamatan (observing), dan refleksi (reflecting). Penelitian dilaksanakan sebanyak dua siklus. Analisis data kualitatif mengacu pada metode analisis Miles dan Huberman meliputi data reduction, data display dan conclusion drawing/verification. Sedangkan data kuantitatif akan dianalisis dengan menggunakan rumus persentasi.

$$
\text { nilai }=\frac{\text { skor siswa }}{\text { skor total }} \times 100 \%
$$

Penentuan taraf keberhasilan secara klasikal dengan menggunakan rumus $b$

$$
\text { ketuntasan }=\frac{\text { jml siswa berhasil }}{\text { jml seluruh siswa }} \times 100
$$


Selanjutnya ditentukan predikat untuk menentukan taraf keberhasilan penelitian seperti pada tabel 1 .

Tabel 1. Prediket kemampuan analisis siswa dalam pembelajaran

\begin{tabular}{ll}
\hline Interval Nilai & Taraf Keberhasilan \\
\hline $85-100$ & A (Sangat Baik) \\
$70-84$ & B (Baik) \\
$55-69$ & C (Cukup) \\
$40-54$ & D (Kurang) \\
$0-39$ & E (Sangat Kurang) \\
\hline
\end{tabular}

\section{HASIL DAN PEMBAHASAN}

Penelitian tindakan kelas ini dilakukan dua siklus dimana hasil penelitian dapat dilaporkan sebagai berikut:

\section{Aktivitas Guru dalam Mengelola Pembelajaran}

Hasil pengamatan terhadap aktivitas guru dalam mengelola pembelajaran menggunakan model picture and picture setiap pertemuan dapat dilihat seperti pada gambar 1.

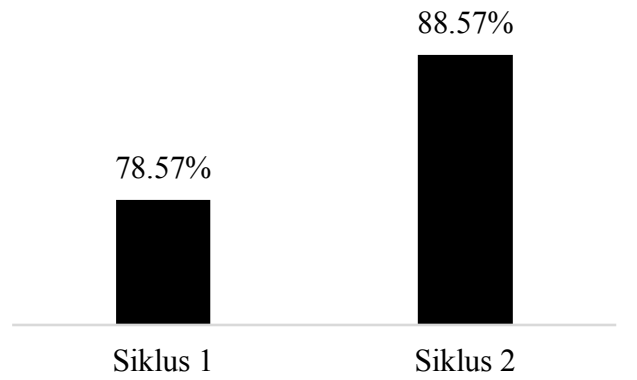

Gambar 1. Aktivitas guru dengan menggunakan model picture and picture melalui ekomik

Pengelolaan kelas yang dilakukan oleh guru baik pada siklus pertaman maupun siklus kedua sudah tergolong baik, dimana pada siklus I mendapatkan skor $78,57 \%$ yang selanjutnya meningkat pada siklus dua $88,57 \%$. Pengelolaan kelas yang baik terlihat dari aktivitas yang dilakukan guru seperti kemampuan membimbing siswa untuk memahami konsep materi pelajaran sesuai dengan indikator ketuntasan belajar, guru juga mampu membimbing siswa jika menemui kendala. Selain itu guru juga memiliki kemampuan untuk mengelola pertanyaan dengan baik. Dengan demikian dapat dikatakan bahwa guru telah melakukan pembelajaran dengan menggunakan model picture and picture berbantukan e-komik dengan sangat baik.

Keberhasilan guru dalam mengelola kelas dikarenakan guru telah memahami sintak model pembelajaran picture and picture dengan baik. Selain itu juga didukung ketersediaan alat-alat dan fasilitas yang memadai yang dapat digunakan sebagai media pembelajaran agar siswa mampu menemukan sendiri cara penyelesaian persoalan yang ada di lembar kerja siswa. Berdasarkan hasil pegamatan juga diketahui bahwa guru telah memberikan pengetahuan yang terbatas kepada siswa di awal pelajaran selanjutnya siswa yang berperan aktif dalam menemukan konsep materi pelajaran melalui serangkaian aktivitas yang telah direncanakan oleh guru.

\section{Aktivitas Siswa selama Pembelajaran}

Hasil pengamatan terhadap aktivitas siswa selama pembelajaran berlangsung dapat dilihat seperti pada gambar 2 .

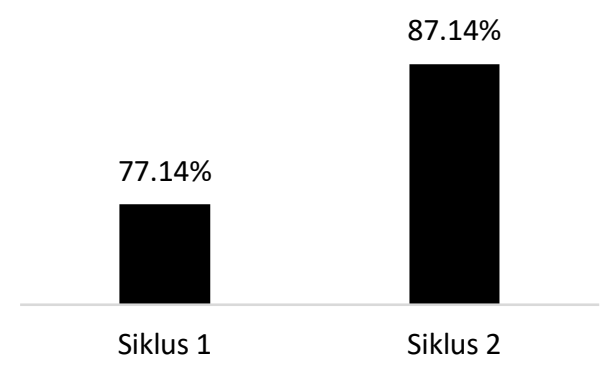

Gambar 2. Aktivitas siswa dengan menggunakan model picture and picture melalui e-komik

Berdasarkan hasil pengamatan terhadap aktivitas siswa selama pembelajaran berlangsung, terdapat 1 poin aktivitas siswa 
yang belum efektif pada siklus I dimana siswa sulit menanyakan hal yang belum dipahami dan setelah melalui refleksi aktivitas tersebut dapat diperbaiki pada siklus 2 yang mana hasil presentase lebih meningkat pada siklus I dari 77,14\% menjadi 87,14\% pada siklus 2 .

Berdasarkan hasil pengamatan dapat diketahui bahwa pembelajaran dengan menggunakan model picture and picture telah menjadikan pembelajaran berpusat kepada siswa dimana aktivitas siswa terlihat lebih dominan dibandungkan dengan guru dalam hal memecahkan permasalahan selama pembelajaran berlangsung. Berdasarkan hasil observasi juga dapat diketahui bahwa aktivias siswa pada setiap indikator yang diamati telah berjalan efektif.

\section{Hasil Belajar Siswa}

Hasil belajar siswa pada materi laju reaksi dengan menggunakan model picture and picture berbantuan e-komik dapat diketahu berdasarkan tes yang telah dilakukan, pemberian tes dilakukan sebanyak tiga kali yaitu pretes, postes siklus I dan postes pada siklus II. Berdasarkan hasil tes maka dapat diketahui berapa banyak siswa yang mengalami peningkatan di setiap siklusnya. Hasil tes selanjutnya digunakan untuk mencari persentase siswa yang belum tuntas berdasarkan KKM yang telah ditentukan pada materi laju reaksi di sub materi faktor-faktor yang mempengaruhi laju reaksi. Adapun persentase ketuntatasan hasil belajar siswa dapat dilihat seperti pada gambar 3 .

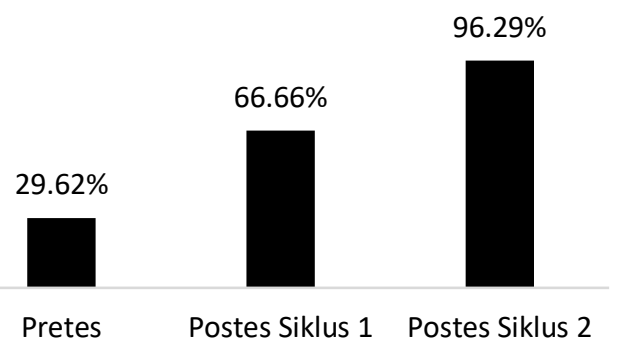

Gambar 3. Persentase ketuntasan belajar siswa dengan menggunakan model picture and picture melalui e-komik
Berdasarkan gambar 3 dapat diketahui bahwa terjadi peningkatan ketuntansan belajar siswa dari $29,62 \%$ pada saat pretes meningkat menjadi $66.66 \%$ pada siklus 1 dan kembali meningkat pada siklus 2 menjadi $96,29 \%$. Terjadinya peningkatan yang signifikan pada siklus 1 menunjukkan bahwa penggunaan model pembelajaran picture and picture terbukti efektif untuk meningkatkan hasil belajar siswa. Sedangkan peningkatan pada siklus 2 dikarenakan guru mencoba mendekati siswa yang belum mampu memecahkan masalah pada tes siklus I untuk memberikan bimbingan, dimana guru memiliki peran yang sangat penting dalam pengingkatan hasil belajar. Dengan demikian penelitian tindakan kelas yang dilaksanakan dengan menerapkan model pembelajaran picture and picture berbantuan media ekomik ini, dapat dikatakan berhasil dengan mencapai kriteria keberhasilan yang ditetapkan, sehingga penelitian dapat dihentikan.

Kerberhasilan dalam penggunaan model pembelajaran picture and picture berbantuan e-komik dapat dijadikan referensi bagi guru bahwa model ini dapat dijadikan alternatif bagi guru untuk meningkatkan aktivitas dan hasil belajar siswa (Baransano, Yohanita, \& Damopolii, 2017; Susanti \& Kusmariyani, 2017; Yuliastanti, 2014). Selain itu keberhasilan penelitian ini juga didukung peran guru dalam pembelajaran dengan menggunakan model picture and picture dalam memfasilitasi serta mengorganisasikan siswa sehingga pembelajaran menjadi lebih efektif serta terarah. Seperti yang kita ketahui bawah guru merupakan salah satu faktor penting dalam meningkatnya hasil belajar siswa (Suwardi \& Farnisa, 2018).

\section{KESIMPULAN}

Penerapan model pembelajaran picture and picture dengan menggunakan e-komik dapat meningkatkan aktivitas dan hasil belajar siswa dimana setiap siklusnya terjadi peningkatan baik aktivitas maupun hasil belajar siswa. Begitu juga dengan aktivitas 
guru terjadi peningkatan menjadi lebih baik untuk setiap siklusnya.

\section{DAFTAR RUJUKAN}

Baransano, A., Yohanita, A., \& Damopolii, I. (2017, Juli 12). Penerapan model pembelajaran picture and picture untuk meningkatkan hasil belajar biologi siswa kelas XI IPA SMA YABT Manokwari.

Elisa, E., \& Wiratmaja, I. G. (2019). Augmented reality: Analisis pengembangan media pembelajaran kimia untuk meningkatkan keterampilan 4C mahasiswa. Journal of The Indonesian Society of Integrated Chemistry, 11(2), 73-81. https://doi.org/10.22437/jisic.v11i2.812 4

Kurniasih, I., \& Sani, B. (2015). Ragam pengembangan model pembelajaran: Untuk peningkatan profesionalitas guru. Jakarta: Kata Pena.

Mirza, M., Kamaruddin, T., \& Abdi, A. W. (2017). Penerapan model pembelajaran picture and picture menggunakan media komik-strip untuk meningkatkan hasil belajar IPS-terpadu siswa kelas VIII-4 SMP Negeri 16 Banda Aceh. Jurnal Ilmiah Mahasiswa Pendidikan Geografi FKIP Unsyiah, 2(3), 68-79.

Puspitasari, E. D. T., Surjono, H. D., \& Minghat, A. D. (2018). Utilizing web based learning as 21 st century learning media for vocational education. International Journal of Engineering \& Technology, 7(4.33), 157-160.
Rinaldi, C. (2006). 30 Kiat Mencetak Anak Kreatif Mandiri. Jakarta: PT. Gramedia.

Rusdi, M. (2009). Orientasi baru teknologi pendidikan kimia. Journal of The Indonesian Society of Integrated Chemistry, 1(1), 46-56. https://doi.org/10.22437/jisic.v1i1.5092

Susanti, P. A., \& Kusmariyani, N. N. (2017). Penerapan model picture and picture berbasis pendekatan saintifik untuk meningkatkan hasil pengetahuan IPA. Jurnal Ilmiah Sekolah Dasar, 1(2).

Suwardi, I., \& Farnisa, R. (2018). Hubungan peran guru dalam proses pembelajaran terhadap prestasi belajar siswa. Jurnal Gentala Pendidikan Dasar, 3, 181-202. https://doi.org/10.22437/gentala.v3i2.6 758

Yuliastanti, D. (2014). Penerapan model pembelajaran picture and picture untuk meningkat hasil belajar pada pembelajaran tematik di sekolah dasar. Jurnal Penelitian Pendidikan Guru Sekolah Dasar, 2(2), 1-10. 